\title{
Description of a new species of a Cestode parasite, Circumoncobothrium devidasensis, from a teleost fish Mastacembelus armatus
}

\author{
A. D. Lakhe \\ Department of Zoology, A.C.S.College, Kille-Dharur, Dist, Beed. Pin-431124, (MS) India
}

\begin{abstract}
The genus Circumoncobothrium was erected by G.B.Shinde in 1968, as a type species Circumoncobothrium ophiocephali from the intestine of fresh water fish Ophiocephalus leucopunctatus. The present form deals with the description of a new species Circumoncobothrium devidasensis, a Cestodian parasite from a teleost fish, Mastacembelus armatus. The worm under discussion is having scolex, long bluntly rounded rostellum with rostellar hooks and contains two bothria. The neck is short, mature segment medium in size, testes and ovary also medium in size. The species shows moderate differences in its morphology and reproductive organs, when compared with the other known species. The above noted characters are valid enough to erect a new species and hence the name Circumoncobothrium devidasensis for this new species is proposed in the honor of authors father.
\end{abstract}

\section{KEY WORDS: CIRCUMONCOBOTHRIUM DEVIDASENSIS, MASTACEMBELUS ARMATUS, MANJRA DAM}

As the genus Circumoncobothrium was erected by G.B. Shinde, in 1968. Latron in 1976 Chincholikar added two new species of the genus C. shindei from fresh water fish Mastacembelus armatus and C. bangariusi from Bangarius species. Shinde in 1977, added a new species C. khami. Jadhav and Shinde in 1980 added two new species C. aurangabadensis and C. raoi. Patil et al., in 1998, Shinde and Kalse in 1999, Tat and Jadhav in 2004, Pardeshi and Kalse in 2007. Supugade et. al, (2005) added C. vitellaiensis from M. armatus. Kharade et al., (2007) added C. cirrihinae from Cirrihina mrigala. Shelke et al., (2007) added C. mehdii from M. armatus. Jawalikar et al. (2008) added C. yogeshwari from $M$. armatus. Borde and Jawale, (2008) added C. purnae from M. armatus. Shah, (2010) added C. paithenensis from M. armatus. Menkudle and Jawale, (2010) added C.

\section{ARTICLE INFORMATION:}

*Corresponding Author: ashokdlakhe@gmail.com Received $2^{\text {nd }}$ Feb, 2018

Accepted after revision $27^{\text {th }}$ March, 2018

BBRC Print ISSN: 0974-6455

Online ISSN: 2321-4007 CODEN: USA BBRCBA

Thomson Reuters ISI ESC / Clarivate Analytics USA and

W. Crossref Indexed Journal

NAAS Journal Score 2017: 4.38 SJIF 2017: 4.196

- A Society of Science and Nature Publication, Bhopal India 2018. All rights reserved.

Online Contents Available at: http//www.bbrc.in/

DOI: $10.21786 / \mathrm{bbrc} / 11.1 / 24$ 
thapari from Ophiocephalus stratus. Pardeshi and Hiware, 2011 added C. Jadhavae from M. armatus. Dhole and Kadam, (2011) added C. clariase from Clarias batrachus. Recently, Fartade and Chati, (2017) have added C. govindii from Channa marulius.

In the present study, the six cestode parasites were collected from the intestine of fresh water fish Mastacembelus armatus. The collected parasites were flattened, preserved in $4 \%$ formalin, stained with Harris haemotoxylin, passed through various alcoholic grades, cleared in xylol and mounted in D.P.X. The whole mount slides were prepared for anatomical studies. The drawings are made with the aid of Camera Lucida.

The scolex was found to be long, bluntly rounded tip, broader in the middle, narrow posteriorly and measured 1.208-1.235 in length and 0.302-0.625 in breadth. The rostellum is medium, transversely elongated, oval and measures 0.038-0.061 in length and 0.112-0.120 in breadth. The rostellar hooks are 48 in number, variable in size, straight, rod like and measures 0.026-0.078in length and 0.003-0.010 in breadth. The bothria are two, extends from anterior to posterior extremity of the scolex, slightly overlapping on each other and measures 0.846-0.897 in length and 0.061-0.072 in breadth. The neck is short and measures 0.030-0.054 in length and $0.276-0.282$ in breadth. The mature segments are medium, broader than long and measures 2.012-2.223 in length and 0.324-0.421 in breadth. The testes are 200210 , medium, round, in two groups on lateral sides of ovary, unequally distributed and measures 0.106-0.113 in diameter. The cirrus pouch is medium, oval, obliquely placed in the middle of the segment and measures 0.1620.181 in length and 0.020-0.088 in breadth.

The cirrus is thin, slightly curved and measures $0.148-0.157$ in length and 0.007 in breadth. The vas deferens is short, thin, slightly curved and measures
0.072-0.079 in length and 0.007 in breadth. The vagina is short, thin tube, runs obliquely and measures 0.1140.140 in length and 0.007 in breadth. The genital pore is small, round, preovarian anterior to isthmus is located in the centre of the segment and measures 0.117-0.126 in diameter. The ovary is medium, bilobed, roughly dumbbell shaped lobes of unequal size, is connected by isthmus and measures 0.535-0.710 in length and 0.024-0.161 in breadth. The isthmus is thick, long and measures 0.146-0.170 in length and 0.043-0.050 in breadth. The ootype is small, rounded, placed between the ovarian lobes and measures 0.086-0.095 in diameter. The vitellaria are granular, 8-10 rows in the corticular region of the segment.

The present communication deals with the description of Circumoncobothrium devidasensis new species. After going through the literature the worm is found to differ from all known species of Circumoncobothrium.

1) The worm under discussion differs from C.ophiocephali, Shinde (1968) in having scolex distinct, rostellar hooks 80, rod shaped, neck present, testes 70-80, ovary single, conical mass to irregular shapes, lobes 2-3, vitellaria in 14-15 rows.2) The present worm differs from C.aurangabadensis, Jadhav and Shinde, (1976) in having the scolex broader in the middle, narrow at both the ends, rostellar hooks 42 in number, rod shaped, neck present, testes 135-145, round, ovary bilobed with 3-4 acini, vitellaria granular, near the lateral margins.3) The present form differs from C.raoi , Shinde and Jadhav, (1976), in having scolex broad in the middle, narrow at both the ends, rostellar hooks 46 in number, rod shaped, testes 210-215, round, in two fields, ovary almost to the posterior margin of the segment, vitellaria granular in the lateral sides of the segment.4) The present worm differs from C.shindei, Shinde and Chincholikar,(1976)in having rostellar hooks 49,rod shaped, neck present, tes-

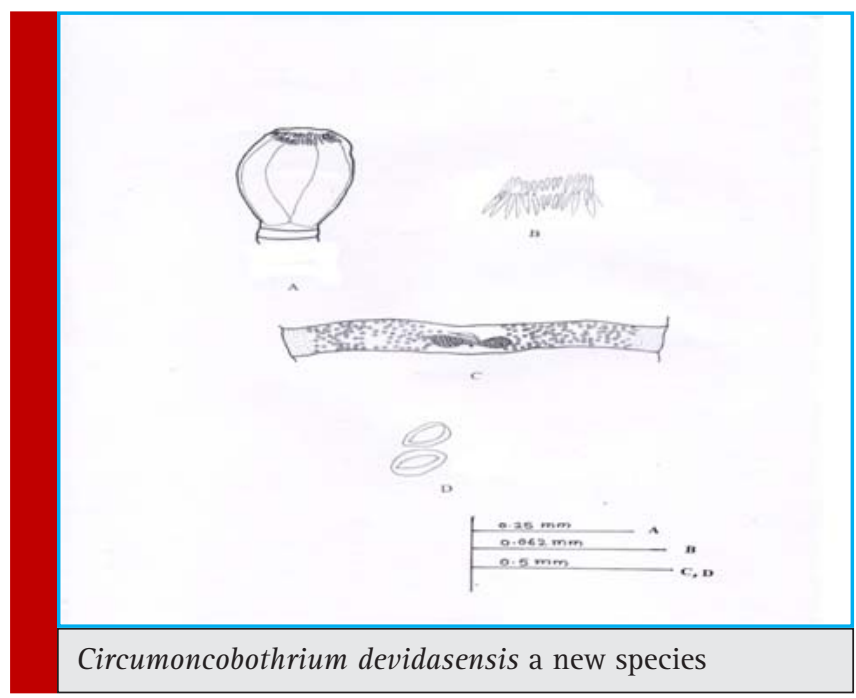

178 DESCRIPTION OF A NEW SPECIES OF A CESTODE PARASITE, CIRCUMONCOBOTHRIUM DEVIDASENSIS 
tes 260-275 (273), round, ovary dumbbell shaped, lobes rounded, situated in the centre of the segment, vitellaria granular. 5) The present cestode differs from C.khami, Shinde,(1976) in having the scolex cylindrical, rostellar hooks 48 in number, mature segment squarish, testes 190-200 (194), rounded, Ovary bilobed, vitellaria follicular, rounded in a single layer, near the lateral margins.

6) The worm under discussion, differs from C. bagariusi, Chincholikar and Shinde, (1976)in having rostellar hooks 55 in numbers, rod shaped, testes 275-285 (278) in number in two fields, ovarian lobes with 5-6 globular acini, in the middle $1 / 3$ of proglottids, vitelline follicles with irregular shape in 4-5 rows on each side.7) The present form differs from C.gachaui, Jadhav and Shinde, (1976)which is having scolex pear shaped in appearance, rostellar hooks 46 in number, neck present, testes 375400 in number, rounded, densely placed in two fields, ovarian lobes with 5-6 short, blunt acini and vitellaria corticular in position with 1-2 rows on each side.8) The worm under discussion differs from C.yamaguti, (Jadhav and Ghavane (1991) which is having rostellar hooks 56 in number, neck present, testes 130-150, rounded, ovary bilobed, centrally placed near posterior margin of proglottids, vitellaria granular, corticular, distributed along lateral margin of proglottids.9) The present worm differs from C.alii, Shinde et.al.(1994) which is having rostellar hooks 34 in number, neck present, testes 230-240 in number in two lateral fields, ovary bilobed, centrally placed compact, vitellaria granular on the lateral fields.

10) The present form differs from C.vadgaonensis, Patil et.al.(1998) which is having scolex large in size, rostellar hooks 56 in number, arranged in four quadrants, neck absent, testes 490-510 in number, oval in shape, ovary distinctly bilobed, each lobe compact in the posterior half of the proglottids, vitellaria follicular, in two rows on each side.11) The present cestode differs from C.baimaii Wongsawad and Jadhav, (1998) in having the scolex pear shaped, hooks 48 in numbers, neck present,testes 88-100 in numbers, ovary compact and reported from Mastacembelus armatus in Chang Mai.12) The present worm differs from C. punctatusi Kalse and Shinde,(1999) in having scolex rectangular, hooks 40-50 in numbers, neck present, mature proglottids squarish, testes 140-150 in numbers, vitellaria follicular, arranged in 3-6 rows and reported from Ophiocephalus punctatus, in India.

13) The present worm differs from $C$. armatusae Shinde et. al., (1999) in having scolex triangular, hooks 58 in numbers, neck present, testes 90-100 in numbers, ovary compact and vitellaria follicular, arranged in 3-4 rows on lateral side of the segments.14) The present parasite differs from C. mastacembelusae Shinde et. al., (2002) in having scolex pear shaped hooks 30 in numbers, testes130-140 in numbers, ovary compact and vitellaria follicular, arranged in 2-3 rows on each lateral side.15) The present cestode differs from C.armatusae (minor) Pawar et. al., (2002) in having scolex triangular, hooks 58 in numbers, testes 190-200 in numbers and vitellaria follicular.16) The present form differs from $C$. manjari Tat andJadhav,(2004) in having the scolex triangular, hooks 48in numbers, in single circle, neck present, testes 128-145 in numbers, vitellaria follicular and reported from Ophiocephalus gachua, in India.17) The present parasite differs from C. vitellariensis Supugade et. al., (2005) in having scolex large, triangular, hook 48 in numbers, testes $250-260$ in numbers and vitellaria follicular, arranged in 3-4 rows.

18) The present parasite differs from $C$. cirrhinae Kharade et al., (2007) in having scolex large, cylindrical, barrel shaped, rostellar hooks 56 , neck short, testes 300305, medium,oval, ovary dumbbell shaped, medium. 19) The present parasitediffers from $C$. mehdii Shelke et al. (2007) in havinghooks 56 arranged in single circle, neck short, squarish, mature segment medium, squarish, testes 280-290 medium, ovary large, distinctly bilobed, vitellaria follicular, 3-4 rows. 20) The present cestode differs from C.ambajogaiensis Pardeshi et al., (2007) in having hooks18-20 in numbers, neck absent, mature segment ten times broader than long, testes 250-300 in numbers, ovary bilobed, dumbbell shaped, vitellaria follicular. 21) The present worm differs from C.yogeshwari Jawalikar et al., (2008) in having hooks 53 in numbers, neck very short, testes 95-98 in numbers, vitellaria follicular, arranged in two rows.

22) The present worm differs from $C$. purnae,Borde and Jawale, (2008) in having hooks 52 in numbers,neck absent, mature segment squarish, slightly broader than long, testes 230-235 in numbers, ovary bilobed and vitellaria follicular, arranged in 3-4 rows. 23) The present parasite differs from C. naidui Kalse et al., (2009) in having scolex cylindrical, hooks 40 in numbers, neck absent, testes 200-210 in numbers, medium rounded, ovary oval, single mass, compact, transversely elongated with acini. 24) The present cestode differs from C. paithenensis Shah, (2010) in having scolex triangular, cylindrical, hooks 58, single circle in four quadrant, neck very short, mature segment two time broader than long, testes 70-80, oval, and vitellaria follicular in tworows. 25) The present form differs from C. thapari Menkudale and Jawale (2010) in having host Ophiocephalus stratus, hooks 52 in numbers, neck absent, testes 95 in numbers, medium, oval, ovary medium, lobed, vitellaria follicular 2-3 rows.

26) The present parasite differs from C. jadhavae Pardeshi and Hiware, (2011) in having scolex triangular, dome shaped, hook 35-45 in numbers, neck present, mature segment broader than long, testes 95-105 oval to round, ovary bilobed, vitellaria follicular, arranged in two rows. 27) The present worm differs from C.clariasi K.N.Kadam and Jaywant Dhole (2011), having scolex triangular, 
hooks 48 in numbers, testes oval in shape 249-259 in numbers, vitellaria follicular arranged 2-3 rows. Reported from Clarias batrachus in India. 28) The worm under discussion differs from C.govindii Fartade and Chati (2017), having scolex conical ,rostellar hooks 58-60 in number, neck present, testes oval to round 50-59 in number, ovary irregular bilobed, vitellaria granular in two rows and reported from Channa marulius.

The above noted characters are valid enough to erect a new species and hence the name Circumoncobothrium devidasensis a new species is proposed in the honor of author's father name from the host Mastacembelus armatus from Manjra dam, Tq.Kaij, Dist.Beed, M.S.India.

$\begin{array}{ll}\text { Type species } & \begin{array}{l}\text { Circumoncobothrium devidasensis, a new } \\ \text { species. }\end{array} \\ \text { Date of collection } & \text { 4th December, 2012. } \\ \text { Host } & \text { Mastacembelus armatus } \\ \text { Habitat } & \text { Intestine } \\ \text { Locality } & \text { Manjra Dam, Taluq Kaij, District. Beed, M.S. } \\ & \text { India. }\end{array}$

\section{REFERENCES}

Borde, S. N. and S. Jawale. (2008): A new species of Ptychobothridae from a fresh water fish in Marathwada region (M.S.).National Journal of Life Sciences. 5 (3):121-124.

Chincholikar, L. N. and G. B. Shinde. (1977): On a new species of Circumoncobothrium Shinde, 1968 (Cestoda:Pseudophyllidea,Carus, 1863) from a fresh water fish in India. Marath. Univ. J.Sci., XVI (Sci. No. 9): 183-185.

Fartade, A.M. and R.S.Chati. (2017): On a new tapeworm Circumoncobothrium govindii of fresh water fish Channa marulius from Godavari basin, India. Biosci.Biotech.Res.comm.10 (2) :63-67.

Jadhav B. V. and G. B. Shinde. (1976): New species of genus Circumoncobothrium Shinde, 1968 (Cestoda:Pseudophyllidea,Carus, 1863) from a freshwater fish Aurangabad, India.Jour. of Indian Bio. Asso. 2: 163 - 166.

Jadhav, B. V. Ghavane AB (1991): On new Pseudophyllidae cestodes from Mastacembelus armatus of Daryapur (M.S.) India. Rivista di Parasitol 7, 19-22

Jawalikar, J. D. S. B. Pawar and G. B. Shinde. (2008): A new cestode Circumoncobothrium yogeshwari n. sp. (Cotyloda:Ptychobothridae) from Mastacembelus armatus. U. P.Journal. of Zoology 28 (3): 399 - 401

Kalse, A.T., Suryawanshi PB Patil JR (2009): On a new species of Circumoncobothrium shinde, 1968 (Cestode:Pseudophyllidea) from a fresh water fish at Chalisgaon, M.S., India, Proc.Zool. Soc.India (I):28-34

Kharade, S. V. Yasmin Mulla and G. B. Shinde. (2007): A new cestode Circumoncobthrium cirrhinae n.sp. (Cotyloda: ptycobothridae) from Cirrhina mrigala. Nat.J.Lif. sci.4 (3)103106.
Pardeshi, K.S. Kalse AT., Andhore VV (2007): A new Pseudophyllidean worm from fresh water fish of Beed (M.S.),Nat.Jour. of life sciences,4(3):107-110.

Pardeshi, P. R. and C. J. Hiware. (2011): A new tapeworm Circumoncobothrium jadhavae n.sp. from Mastacembelus armatus (Lecepede) 1800, at Aurangabad M.S.India. Recent Research in Science and Technology 3(3): 20-25.

Patil, S.R Kalse AT Patil JR (2009): A new Pseudophyllidean worm from a fresh water fish at Umberkhede,Jalgaon,India. Geobios,36(1):45-48.

Patil,J.R. Murhar B.M.and Kalse,A.T.(2008): On a new species of the genus Circumoncobothrium Shinde,1968 (Cestoda:Pseu dophyllidea;Carus,1863) from fresh water fish at Jamda,Dist. Jalgaon,India.Deccan Current Sci.1(1) 2-5.

Pawar, S. B. (2002): A new species Circumoncobothrium armatusae n.sp. (Cestoda: Pseudophyllidae) from Mastacembelus armatus at Paithan, India. Riv. Di. Parasit. Vol. XX (LXIII) No.3:219-222.

Shah, Shabbir Ahmed Yasin. (2010): Taxonomic observations of Circumoncobothrium paithenensis n. sp. from fresh water fish Mastacembelus armatus International Journal of Systems Biology,Volume 2, Issue 2, 2010, pp-21-24.

Shelke, V. P. (2007): A new Ptychobothridae tapeworm from Mastacembellus armatus at Aurangabad (M.S.) Nat.J.Lif. sci.4(3) (72-74).

Shinde, G. B. (1977): On a new species of Circumoncobothrium Shinde, 1968 (Cestoda: Pseudophyllidea Carus, 1863) from freshwater fish, M.S.Ibid., XVI: 129-133.

Shinde, G. B., Sarwade, D. V., Jadhav, B. V. and M. A. Mahajan. (1994): On a new species of the genus Circumoncobothrium Shinde, 1968 (Cestoda:Pseudophyllidae) Carus, 1863 from Mastacembelus armatus (Cuv. and Val.) from freshwater fish at Aurangabad (M.S.) India. Rivista Di Parasitologia11 (55):167169.

Shinde, G. B. and A. T. Kalse. (1999): Two new species of genus Circumoncobothrium Shinde, 1968 (Cestoda:Pseudophylidea Carus, 1863) from a freshwater fish at Khandesh (M.S.). Rivista Di. Parasitol., XVI (LX) N.3: 195-198.

Shinde, G. B., Pawar, S. B. and S. P. Chauhan. (2002): A new species Circumoncobothrium mastacembellusae n.sp. (Cestoda:Pseudophyllidae) from Mastacembelus armatus at Paithan, India. Riv. Di. Parasit., Vol. XX (LXII)No. 3: 195198.

Supugade, (2005): Circumoncobothrium vitellariensis n.sp. Ptycobothriidae (Luhe, 1920) from Mastacembelus armatus (M.S.), India. Trajectory, Vol. 13 No. 1: 43-49.

Tat, M. B. and B. V. Jadhav. (2004): A new species of the genus Circumoncobothrium Shinde, 1968 (Cestoda: Pseudophyllidea) Carus, 1863 from Ophiocephalus gachua at Dhanegaon, Dist. Beed. Nat. Jour. of Life Sciences. 1 (1):129-132.

Wongsawad, C. and B. V. Jadhav. (1998): Circumoncobothrium baimaii n.sp. (Cestoda: Pseudophyllidae) from fresh water fish, Maesa Chiang Mai, Thailand. Rivista Di Parasitologia.Vol. XV(LIX)No.3:291-294 